\title{
Recent advances in management of cerebrovascular diseases
}

\section{Khurshid Khan* and Ashfaq Shuaib}

\author{
Address: Division of Neurology, University of Alberta, Edmonton, Alberta T6G 2B7, Canada \\ *Corresponding author: Khurshid Khan (kakhan@ualberta.ca) \\ FI000 Medicine Reports 2009, I:49 (doi:10.3410/MI-49) \\ The electronic version of this article is the complete one and can be found at: http://FI000.com/Reports/Medicine/content/I/49
}

\begin{abstract}
A comprehensive approach to managing the vascular risk factors in both primary and secondary stroke prevention settings can lower the risk of first and recurrent stroke. Recent studies highlight the benefits of blood pressure treatment in the elderly, use of statins in healthy subjects with normal low-density lipoprotein levels, and comparison of various anti-platelet agents. For acute stroke the efficacy of thrombolysis beyond 3 hours has recently been shown.
\end{abstract}

\section{Introduction and context}

Stroke is the second most common cause of death worldwide and the leading cause of disability, resulting in a huge financial impact on our health care systems. The lifetime direct and indirect cost of major types of strokes was estimated to be in excess of $\$ 40$ billion in the USA in an incidence-based model assessed by Taylor and colleagues for the year 1990 [1]. The incidence of stroke steadily decreased from the early 1950 s to the mid1980s. It then plateaued for a decade but is on the rise again. There is a general consensus that the significant decrease in stroke incidence was a result of better control of risk factors. The recent increase in incidence is related to the rising percentage of older people in the community. This brief review will focus on three important areas of recent advances in the management of cerebrovascular diseases. Discussion relating to primary prevention focuses on advances in management of hypertension and hyperlipidemia. Secondly, we review recent developments in the use of appropriate antithrombotic therapy in patients with transient ischemic attacks (TIAs) and acute stroke. Finally, we review recent advances in management of acute ischemic stroke to limit neuronal damage, before reviewing the implications that all three areas have for clinical practice.

\section{Recent advances}

\section{Primary prevention and cerebrovascular disease}

Stroke is a heterogeneous disorder with varying underlying etiologies and associated modifiable vascular risk factors. With early intervention, these modifiable risk factors may be controlled and, hence, the incidence of cerebrovascular events reduced.

\section{Hypertension}

Hypertension is the most common and important risk factor for all types of strokes. Across World Health Organization regions, research indicates that about $62 \%$ of strokes and $49 \%$ of heart attacks are caused by high blood pressure [2]. There is evidence that even highnormal blood pressure (systolic 130-139 and diastolic $85-89 \mathrm{mmHg}$ ) is a marker of an elevated risk of cardiovascular disease in both genders and the young and the old (age range 35-90 years) [3,4]. About twothirds of the cerebrovascular disease burden is attributable to non-optimum blood pressure control [2].

Multiple studies have shown a $30-40 \%$ reduction of recurrent stroke with treatment of hypertension [5]. Benefits are seen irrespective of the class of antihypertensive agents and the severity of hypertension [6]. Several categories of antihypertensive agents, including thiazide diuretics, angiotensin-converting enzyme inhibitors, angiotensin receptor blockers, adrenergic receptor blockers, and calcium channel blockers, reduce cardiovascular risk, including the risk of stroke, in patients with hypertension. The benefits of optimum blood pressure therapy have been shown even in older people. A recent prospective randomized placebo controlled study of individuals $\geq 80$ years of age with a sustained systolic 
blood pressure of $\geq 160 \mathrm{mmHg}$ showed beneficial outcome with antihypertensive treatment. In this study, more than 3,800 individuals were enrolled, of whom only $11.8 \%$ had cardiovascular history, and were treated with indapamide $(1.5 \mathrm{mg}$ ) with or without perindopril (2-4 mg). A mean blood pressure reduction of $15 / 1 \mathrm{mmHg}$ was achieved in the active arm compared to placebo. A significant 39\% reduction in the strokerelated death rate was noted at 2 years $(P=0.05)$. A 30\% reduction in fatal and non-fatal strokes $(P=0.06)$ and a $64 \%$ reduction in heart failure $(P=0.001)$ was achieved [7]. These findings give credence to both the efficacy and the safety of treating hypertension in very old people.

In summary, there is compelling evidence that treatment of hypertension is associated with a significant reduction of first ever stroke and stroke-related death in the young and the old. The cornerstone to successful outcome is instituting sustained lifestyle changes and early pharmacotherapy to achieve target goals as recommended by the Canadian Hypertension Education Program (CHEP) 2009 ( $<140 / 90 \mathrm{mmHg}$; $<130 / 80 \mathrm{mmHg}$ in diabetes and renal failure) [8]. The choice of antihypertensive therapy may be dictated by other cardiovascular conditions.

\section{Dyslipidemia}

There is no clear evidence of an association between rising levels of serum cholesterol and the risk of cerebrovascular disease. There is, however, evidence from randomized trials that statins can reduce the risk of stroke. In the Heart Protection Study the incidence of first ever stroke was reduced by $29 \%$ with simvastatin compared to placebo [9]. This effect was seen independent of a history of previous vascular disease and the level of serum cholesterol levels. Other studies have shown similar results [10].

The recently published JUPITER trial (which included 17,802 patients) tested the effects of rosuvastatin versus placebo in otherwise healthy subjects with normal lowdensity lipoprotein (LDL) levels $(<3.4 \mathrm{mmol} / \mathrm{L})$ and elevated high-sensitivity C-reactive protein ( $\geq 2 \mathrm{mg}$ ) and showed significant reductions in major cardiovascular events $(16 \%$ in stroke, $P=0.002 ; 20 \%$ in myocardial infarction, $P=0.002$; and $40 \%$ in the composite endpoint of myocardial infarction, stroke, revascularization and death, $P=0.00001$ ). The median LDL and highdensity lipoprotein levels were 2.8 and $1.3 \mathrm{mmol} / \mathrm{L}$, respectively, in both active and placebo arms. Rosuvastatin reduced LDL by $50 \%$ and C-reactive protein by $37 \%$. There was no difference in intracranial hemorrhage between the two groups (six in the rosuvastatin group and nine in the placebo group) [11].
A single large trial, the Stroke Prevention by Aggressive Reduction in Cholesterol Levels (SPARCL) trial, studied the use of statins in patients with cerebrovascular disease without cardiac history. This trial randomized 4,731 patients with LDL levels of $2.6-4.9 \mathrm{mmol} / \mathrm{L}$ to receive atorvastatin $80 \mathrm{mg}$ or placebo. The 5-year absolute risk reduction for fatal and non-fatal stroke was 2.2\% (unadjusted hazard ratio $P=0.05$ ) and for major cardiovascular events was 3.5\% $(P=0.002)$. This overall reduction in the incidence of stroke and other cardiovascular events was noted despite a small increase in hemorrhagic strokes [12].

\section{Secondary prevention and cerebrovascular disease}

The risk of a completed stroke in patients with a TIA is approximately $10.5 \%$ at 90 days. This is especially high in patients with a history of hypertension or diabetes, in whom the neurological symptoms last for over 10 minutes and consist of focal weakness or aphasia. The 2-day risk of stroke in such patients may be as high as 8\% [13]. Recent evidence from two independent studies has shown that the 90-day risk can be reduced by as much as $80 \%$ if patients are evaluated and their treatment initiated within 24 hours of the onset of symptoms $[14,15]$. It is imperative that we improve our ability to rapidly asses and manage such patients. In addition to the liberal use of antihypertensive and statin therapy, as outlined above in the discussion on primary prevention, such patients also require immediate antithrombotic therapy.

Antithrombotic treatment options are limited to aspirin [acetylsalicylic acid (ASA)], clopidogrel, and a combination of ASA and extended release dipyridamole (ASA+ERDP). The recently published guidelines on antithrombotic therapy would suggest that any one of the three agents is indicated as the first-line therapy for stroke prevention in patients with TIA or ischemic stroke of non-cardiac origin. [16] Clopidogrel and ASA+ERDP are, however, significantly more expensive than ASA and may have relatively more side effects. Studies have compared the relative efficacy of ASA to clopidogrel or ASA to ASA+ERDP. In such studies, these agents have shown better results when compared to ASA. The effect has been marginal with clopidogrel (absolute difference $0.5 \%$ and relative risk reduction 11\%) [17]. With ASA+ERDP, this effect was more robust (relative risk reduction of $37 \%$ ) [18].

Until recently, however, no studies had compared clopidogrel to ASA+ERDP in stroke prevention. The Prevention Regimen for Effectively Avoiding Second Strokes (PRoFESS) trial published last year was the first large study to compare the efficacy of clopidogrel to 
ASA+ERDP in patients with ischemic stroke [19]. Over 20,000 patients were followed for 4 years and the primary outcome was the occurrence of recurrent ischemic stroke. Secondary outcomes included the incidence of serious complications, including development of systemic or intracerebral hemorrhage. There was no significant difference in the development of recurrent stroke in the two treatment groups. There were, however, more complications, including an increased risk of intracerebral hemorrhage, in the ASA+ERDP-treated group. Despite the excess in hemorrhagic strokes, the number of patients with fatal or disabling strokes was similar in both groups [19]. In antiplatelet naïve patients, it is our preference to start patients on ASA as the first-line therapy. Patients who are unable to tolerate ASA may be treated with clopidogrel.

At present there is no evidence that the combination of ASA with clopidogrel is superior to the use of singleagent treatment. Such combinations are routinely used in patients with acute coronary syndromes or in patients who require arterial stenting. The Management of Atherothrombosis with Clopidogrel in High-risk Patients with Recent TIA or Ischemic Stroke (MATCH) study showed that the combination was no better than clopidogrel alone, but did increase the risk of symptomatic intracerebral hemorrhage in patients with stable TIAs or ischemic stroke [20]. The combination is therefore not recommended in stroke prophylaxis. A recent preliminary study, the Fast Assessment of Stroke and Transient Ischaemic Attack to Prevent Early Recurrence (FASTER) trial, however, showed that in the very acute phase after onset of a TIA, the combination might be superior to ASA alone [21]. FASTER was, however, a feasibility study. A larger FASTER II study is in the planning stages and may answer this important question on the use of combination antithrombotic therapy for a short time in patients very early after presenting with a TIA.

\section{Management of acute stroke}

\section{Thrombolysis}

Thrombolysis using intravenous tissue plasminogen activator (tPA) has been available as a treatment for acute ischemic stroke for more than a decade. Until recently, the use was limited to only a 3-hour treatment window from the time of onset of the symptoms. This narrow therapeutic window resulted in a low rate of thrombolysis. Recently, the European Cooperative Acute Stroke Study (ECASS) III study assessed efficacy of intravenous tPA up to 4.5 hours from the time of onset of stroke symptoms [22]. The study was carried out in multiple centers in Europe. This study enrolled 821 patients between 3 and 4.5 hours after stroke onset.
The primary end point was disability at 90 days, dichotomized as a favorable outcome (a score of 0 or 1 ) or an unfavorable outcome (a score of 2 to 6) on the modified Rankin Scale (mRS). The secondary end point was a global outcome analysis of four neurological and disability scores combined. Safety end points included death, symptomatic intracranial hemorrhage, and other serious adverse events. The outcome was in favor of tPA (52.4 versus $45.2 \%, P=0.04$ ). The incidence of intracranial hemorrhage was higher with tPA than with placebo (for any intracranial hemorrhage, 27.0 versus $17.6 \%$, $P=0.001$; for symptomatic intracranial hemorrhage, 2.4 versus $0.2 \%, P=0.008)$. Mortality did not differ significantly between the tPA and placebo groups (7.7 and $8.4 \%$, respectively; $P=0.68$ ) [22]. It is expected that, with the results of ECASS III, health regulatory bodies in North America, Europe and elsewhere would soon be recommending an extension of the treatment window with tPA to 4.5 hours in eligible patients with acute stroke. Despite the positive outcome in the extended therapeutic window, very early treatment remains the goal for good outcome and, therefore, ultra-fast intervention must be ensured.

\section{Stroke units}

Stroke care can be optimized by enhancing transition from the emergency room to a specialized stroke unit with stroke expertise in nursing care, cardiac monitoring, early physiotherapy with rapid initiation of aggressive post-stroke rehabilitation and multidisciplinary dispensation planning. Randomized studies have confirmed association of improved outcomes with designated stroke units in terms of reduced mortality, functional independence and need for institutionalized care after the stroke [23]. This beneficial effect has been shown to be consistent [24] and also seen in a routine clinical practice in a large multicenter observational study analyzing more than 17,000 ischemic stroke admissions across a large Australian population [25]. Hospitals are encouraged to develop such units if they admit stroke patients regularly. Admission to stroke units would significantly decrease the risk of complications, reduce the length of stay, and allow for a larger percent of patients to be discharged home.

\section{Decompressive hemicraniectomy for large strokes}

Recently, in three randomized studies, hemicraniectomy performed within 48 hours of stroke onset has been compared to medical management alone. A pooled analysis of patients (93 patients aged $<60$ years) with malignant stroke in the middle cerebral artery territory indicated a significantly lower 1-year mortality with a probability of survival increasing from 28 to $80 \%$ and a significantly larger proportion with a 1-year outcome of 
mRS score $<3$ after hemicraniectomy $(\mathrm{n}=51)$ compared to medical management alone $(n=42)$ [26]. The functional outcome does not appear to improve if hemicraniectomy is delayed beyond 48 hours [27]. However, the relevance of hemispheric dominance, the extension of infarcted brain, and whether the reduced mortality justifies the morbidity among survivors remain to be answered. The decision to perform hemicraniectomy in patients with massive brain infarction must be made on an individual basis and in centers with such experience.

\section{Implications for clinical practice Hypertension and hyperlipidemia}

Multiple studies show significant reduction in the incidence of stroke with hypertension treatment. Even in the very old, treatment of hypertension does not impact negatively. Therefore, judicial use of antihypertensives should be considered for optimum blood pressure control.

There is evidence from several trials in high-risk patients without cerebrovascular disease that treatment with statins will significantly reduce the risk of stroke. SPARCL showed that this effect was also evident in patients with established cerebrovascular disease. Canadian, USA, and European guidelines recommend that in high-risk patients with cerebrovascular disease, LDL levels should be targeted to less than $2 \mathrm{mmol} / \mathrm{L}$. This requires the use of high dose statins in most patients.

\section{Secondary prevention and cerebrovascular disease}

Early intervention should be instituted in patients with high-risk TIAs. There is no strong evidence for dual antiplatelet therapy in stroke prevention. We consider aspirin as the first antiplatelet choice in aspirin-naïve patients unless there is intolerance to aspirin. There is some evidence that short-term combination of ASA and clopidogrel may be more efficacious in the acute phase, however, the latter warrants further evidence. Optimum antithrombotic prophylaxis, blood pressure and cholesterol management to currently recommended targets must be implemented to reduce recurrence of TIA or stroke.

\section{Management of acute stroke}

The window for thrombolytic treatment of acute ischemic stroke is expected to be extended to 4.5 hours but ultra-rapid revascularization remains the goal to realize best neurological and functional outcomes. Specialized post-stroke care in stroke units helps mitigate medical complications, and early rehabilitation leads to better recovery and independence. Following a malignant anterior circulation stroke the decision about craniectomy must be individualized.

\section{Abbreviations}

ASA, acetylsalicylic acid; CHEP, Canadian Hypertension Education Program; ECASS, European Cooperative Acute Stroke Study; ERDP, extended release dipyridamole; FASTER, Fast Assessment of Stroke and Transient Ischaemic Attack to Prevent Early Recurrence; JUPITER, Justification for the Use of Statins in Primary Prevention: an Intervention Trial Evaluating Rosuvastatin; LDL, lowdensity protein; MATCH, Management of Atherothrombosis with Clopidogrel in High-risk Patients with Recent TIA or Ischemic Stroke; mRS, modified Rankin Scale; PRoFESS, Prevention Regimen for Effectively Avoiding Second Strokes; SPARCL, Stroke Prevention by Aggressive Reduction in Cholesterol Levels; TIA, transient ischemic attack; tPA, tissue plasminogen activator.

\section{Competing interests}

KK declares that he has no competing interests. AS declares that he has received personal compensation and research support from: AstraZeneca Plc; CoAxia, Inc; Pfizer, Inc; Boehringer Ingelheim GmbH; Sanofi-Aventis; Servier Laboratories; Merck Frosst Ltd; Bayer AG; Neurobiological Technologies, Inc; Allphase Clinical Research Services, Inc; Bristol-Myers Squibb; and Aventis.

\section{References}

I. Taylor TN, Davis PH, Torner JC, Holmes J, Meyer JW, Jacobson MF: Lifetime cost of stroke in the United States. Stroke 1996, 27:1459-66.

2. World Health Organization: The World Health Report 2002: Reducing Risk, Promoting Healthy Life. [http://www.who.int/ whr/2002/en/].

3. Vasan RS, Larson MG, Leip EP, Evans JC, O'Donnell CJ, Kannel WB, Levy D: Impact of high-normal blood pressure on the risk of cardiovascular disease. N Engl J Med 200I, 345:129|-97.

4. Turnbull F; Blood Pressure Lowering Treatment Trialists' Collaboration: Effects of different blood-pressure-lowering regimens on major cardiovascular events: results of prospectively-designed overviews of randomised trials. Lancet 2003, 362: 1527-35.

5. Lawes CM, Bennett DA, Feigin VL, Rodgers A: Blood pressure and stroke: an overview of published reviews. Stroke 2004, 35:776-85.

6. Turnbull F, Neal B, Algert C, Chalmers J, Chapman N, Cutler J, Woodward M, MacMahon S; Blood Pressure Lowering Treatment Trialists' Collaboration: Effects of different blood pressurelowering regimens on major cardiovascular events in individuals with and without diabetes mellitus: results of prospectively designed overviews of randomized trials. Arch Intern Med 2005, 165:1410-9.

7. Beckett NS, Peters R, Fletcher AE, Staessen JA, Liu L, Dumitrascu D, Stoyanovsky V, Antikainen RL, Nikitin Y, Anderson C, Belhani A, Forette F, Rajkumar C, Thijs L, Banya W, Bulpitt CJHYVET Study Group: Treatment of hypertension in patients 80 years of age or older. N Engl J Med 2008, 358: 1887-98.

\section{Changes Clinical Practice}

Factor I0.7 Exceptional

Evalauted by Deepak Bhatt 14 Apr 2008, Ramachandran S Vasan 15 Apr 2008, Jerome Fleg 18 Apr 2008, Annemarie Hennessy 29 Apr 2008, Ernesto Schiffrin 02 May 2008, Wilbert Aronow, 07 May 2008, Kazuomi Kario 03 Jun 2008

8. Canadian Hypertension Education Program (CHEP). [http:// www.hypertension.ca/chep/]. 
9. Heart Protection Study Collaborative Group: MRC/BHF Heart Protection Study of cholesterol lowering with simvastatin in 20,536 high-risk individuals: a randomised placebo-controlled trial. Lancet 2002, 360:7-22.

10. Bersano A, Ballabio E, Lanfranconi S, Mazzucco S, Candelise L, Monaco S: Statins and stroke. Curr Med Chem 2008, 15:2380-92.

II. Ridker PM, Danielson E, Fonseca FA, Genest J, Gotto AM Jr, Kastelein JJ, Koenig W, Libby P, Lorenzatti AJ, MacFadyen JG, Nordestgaard BG, Shepherd J, Willerson JT, Glynn RJ; JUPITER Study Group: Rosuvastatin to prevent vascular events in men and women with elevated C-reactive protein. N Engl J Med 2008, 359:2195-207.

\section{Changes Clinical Practice}

Factor 10.0 Exceptional

Evaluated by Melvin Cheitlin 28 Nov 2008, Seth Field 09 Feb 2009 , Judy Kersten 26 Mar 2009, Conrado Estol 30 Mar 2009, Philipp M Lepper 08 Apr 2009

12. Amarenco P, Bogousslavsky J, Callahan A 3rd, Goldstein LB, Hennerici M, Rudolph AE, Sillesen H, Simunovic L, Szarek M, Welch KM, Zivin JA; Stroke Prevention by Aggressive Reduction in Cholesterol Levels (SPARCL) Investigators: High-dose atorvastatin after stroke or transient ischemic attack. N Engl J Med 2006, 355:549-59.

Changes Clinical Practice

Factor 6.0 Must Read

Evaluated by Mitch Elkind 06 Sep 2006

13. Johnston SC, Rothwell PM, Nguyen-Huynh MN, Giles MF, Elkins JS, Bernstein AL, Sidney S: Validation and refinement of scores to predict very early stroke risk after transient ischaemic attack. Lancet 2007, 369:283-92.

Factor 6.0 Must Read

Evaluated by Mitch Elkind 04 Oct 2007

14. Rothwell PM, Giles MF, Chandratheva A, Marquardt L, Geraghty O, Redgrave JN, Lovelock CE, Binney LE, Bull LM, Cuthbertson FC, Welch SJ, Bosch S, Alexander FC, Silver LE, Gutnikov SA, Mehta Z; Early use of Existing Preventive Strategies for Stroke (EXPRESS) study: Effect of urgent treatment of transient ischemic attack and minor stroke on early recurrent stroke (Express study): a prospective population based sequential comparison. Lancet 2007, 370: 1432-42.

\section{Changes Clinical Practice}

Factor 6.4 Must Read

Evaluated by Ashfaq Shuaib 26 Mar 2008, Conrado Estol 19 Jun 2008

15. Lavallée PC, Meseguer E, Abboud H, Cabrejo L, Olivot JM, Simon O, Mazighi M, Nifle C, Niclot P, Lapergue B, Klein IF, Brochet E, Steg PG, Lesèche G, Labreuche J, Touboul PJ, Amarenco P: A transient ischaemic attack clinic with round-the-clock access (SOSTIA): feasibility and effects. Lancet Neurol 2007, 6:953-60.

16. Albers GW, Amarenco P, Easton JD, Sacco RL, Teal P; American College of Chest Physicians: Antithrombotic and thrombolytic therapy for ischemic stroke: American College of Chest Physicians Evidence-Based Clinical Practice Guidelines (8th Edition). Chest 2008, I33 (Suppl 6): 630S-69S.

17. CAPRIE Steering Committee: A randomised, blinded, trial of clopidogrel versus aspirin in patients at risk of ischaemic events (CAPRIE). Lancet 1996, 348: I329-39.

18. Diener HC, Cunha L, Forbes C, Sivenius J, Smets P, Lowenthal A: European Stroke Prevention Study. 2. Dipyridamole and acetylsalicylic acid in the secondary prevention of stroke. J Neurol Sci 1996, 143:1-I3.

19. Diener HC, Sacco RL, Yusuf S, Cotton D, Ounpuu S, Lawton WA, Palesch Y, Martin RH, Albers GW, Bath P, Bornstein N, Chan BP, Chen ST, Cunha L, Dahlöf B, De Keyser J, Donnan GA, Estol C,
Gorelick P, Gu V, Hermansson K, Hilbrich L, Kaste M, Lu C, Machnig T, Pais P, Roberts R, Skvortsova V, Teal P, Toni D et al.; Prevention Regimen for Effectively Avoiding Second Strokes (PRoFESS) study group: Effects of aspirin plus extended-release dipyridamole versus clopidogrel and telmisartan on disability and cognitive function after recurrent stroke in patients with ischaemic stroke in the Prevention Regimen for Effectively Avoiding Second Strokes (PRoFESS) trial: a double-blind, active and placebo-controlled study. Lancet Neurol 2008, 7:875-84.

20. Diener HC, Bogousslavsky J, Brass LM, Cimminiello C, Csiba L, Kaste M, Leys D, Matias-Guiu J, Rupprecht HJ; MATCH investigators: Aspirin and clopidogrel compared with clopidogrel alone after recent ischaemic stroke or transient ischaemic attack in high-risk patients (MATCH): randomised, double-blind, placebo-controlled trial. Lancet 2004, 364:331-7.

21. Kennedy J, Hill MD, Ryckborst KJ, Eliasziw M, Demchuk AM, Buchan AM; FASTER Investigators: Fast Assessment of Stroke and Transient Ischaemic Attack to Prevent Early Recurrence (FASTER): a randomised controlled pilot trial. Lancet Neurol 2007, 6:96I-9.

Factor 3.0 Recommended

Evaluated by Mitch Elkind 30 Apr 2008

22. Hacke W, Kaste M, Bluhmki E, Brozman M, Dávalos A, Guidetti D, Larrue V, Lees KR, Medeghri Z, Machnig T, Schneider D, von Kummer R, Wahlgren N, Toni D; ECASS Investigators: Thrombolysis with alteplase 3 to $\mathbf{4 . 5}$ hours after acute ischemic stroke. N Engl J Med 2008, 359:1317-29.

\section{Changes Clinical Practice}

Factor 9.8 Exceptional

Evaluated by Megan Leary 10 Oct 2008, Bo Norrving 03 Nov 2008, Samuel Stratton I3 Nov 2008

23. Díez-Tejedor E, Fuentes B: Acute care in stroke: do stroke units make the difference? Cerebrovasc Dis 200I, I I(Suppl I):3I-9.

24. Fuentes $B$, Díez-Tejedor E, Ortega-Casarrubios MA, Martínez $P$, Lara M, Frank A: Consistency of the benefits of stroke units over years of operation: an 8-year effectiveness analysis. Cerebrovasc Dis 2006, 21:173-9.

25. Gattellari M, Worthington J, Jalaludin B, Mohsin M: Stroke unit care in a real-life setting: can results from randomized controlled trials be translated into every-day clinical practice? An observational study of hospital data in a large Australian population. Stroke 2009, 40:10-7.

26. Vahedi K, Hofmeijer J, Juettler E, Vicaut E, George B, Algra A, Amelink GJ, Schmiedeck P, Schwab S, Rothwell PM, Bousser MG, van der Worp HB, Hacke W; DECIMAL, DESTINY, and HAMLET investigators: Early decompressive surgery in malignant infarction of the middle cerebral artery: a pooled analysis of three randomised controlled trials. Lancet Neurol 2007, 6:215-22.

\section{Changes Clinical Practice}

Factor 6.4 Must Read

Evaluated by Mitch Elkind 04 Oct 2007, Andreas Kramer 12 Mar 2008

27. Hofmeijer J, Kappelle LJ, Algra A, Amelink GJ, van Gijn J, van der Worp; HB; HAMLET investigators: Surgical decompression for space-occupying cerebral infarction (the Hemicraniectomy After Middle Cerebral Artery infarction with Life-threatening Edema Trial [HAMLET]): a multicentre, open, randomised trial. Lancet Neurol 2009, 8:326-33.

Factor 4.8 Must Read

Evaluated by Nicola Latronico 20 Mar 2009, Opeolu Adeoye 27 May 2009 